\title{
PEMANFAATAN PLATFORM VIDEO ONLINE MENGENAI PENATALAKSANAAN KEDARURATAN AVULSI GIGI DI MASA PANDEMI COVID-19
}

DOI: https://doi.org/10.33024/jkpm.v4i5.4338

\author{
Cristiani Nadya Pramasari ${ }^{*}$, Nydia Hanan² \\ 1,2 Program Studi Kedokteran Gigi, Fakultas Kedokteran, \\ Universitas Mulawarman
}

Disubmit: 09 Mei 2021

Diterima: 28 Mei 2021

Diterbitkan: 02 Oktober 2021

Email Korespondensi: nadya.pramasari@fk.unmul.ac.id

\begin{abstract}
ABSTRAK
Avulsi gigi merupakan jenis cedera umum yang mengakibatkan gigi terlepas dari soket alveolar. Jenis trauma dentoalveolar ini menyebabkan ligamen periodontal terputus dengan atau tanpa fraktur tulang alveolus. Meskipun perawatan yang ideal adalah replantasi gigi segera di tempat terjadinya trauma, hal ini mungkin tidak dapat dilakukan secara praktis dalam setiap kasus. Masyarakat masih belum mengetahui upaya pertolongan pertama pada penatalaksanaan avulsi gigi sebelum dilakukan replantasi untuk mempertahankan viabilitas jaringan di sekitar gigi yang lepas. Kegiatan pengabdian kepada masyarakat ini dilaksanakan untuk meningkatkan pengetahuan masyarakat tentang cara membersihkan dan menyimpan gigi dengan tepat yang bertujuan meningkatkan keberhasilan perawatan di masa pandemi Covid-19. Pelaksanaan kegiatan kepada masyarakat ini meliputi pembuatan video animasi edukasi dan pengunggahan video tersebut pada platform video online "Youtube". Respon yang diperoleh dari masyarakat dilakukan melalui kuesioner. Pengisian kuesioner oleh masyarakat (50 orang) didapatkan hasil yaitu sebanyak $50 \%$ sangat puas ; $48 \%$ puas ; $2 \%$ cukup puas ; $0 \%$ tidak puas ; dan $2 \%$ sangat tidak puas terhadap video edukasi yang ditayangkan pada platform YouTube tersebut. Tingginya kepuasan masyarakat diharapkan diimbangi dengan peningkatan pengetahuan dan kesadaran masyarakat tentang penatalaksanaan kedaruratan avulsi gigi di masa pandemi Covid-19 yang disajikan dari video animasi edukasi.
\end{abstract}

Kata Kunci: Avulsi gigi, ligamen periodontal, replantasi gigi, trauma dentoalveolar

\begin{abstract}
Dental avulsion is a common type of injury that causes teeth to detach from the alveolar socket. This type of dentoalveolar trauma results in severed periodontal ligaments with or without alveolar bone fracture. Although the ideal treatment is dental replantation immediately at the site of the trauma, this may not be practicable in every case. The community still does not know the first aid efforts in the management of dental avulsion before replanting to maintain the viability of the tissue around the loose tooth. This community service activity is carried out to increase community knowledge about how to clean and store teeth properly with the aim of increasing the success of treatment in Covid-19 pandemic. The implementation of this activity to the
\end{abstract}


community includes making educational animated videos and uploading them to the online video platform "Youtube". The responses obtained from the community were carried out through a questionnaire. Filling out the questionnaire by the community (48 peoples) showed that $42 \%$ were very satisfied; $48 \%$ satisfied; $6 \%$ were quite satisfied; $0 \%$ dissatisfied; and $4 \%$ are very dissatisfied with the educational video shown on YouTube platform. The high level of community satisfaction is expected to be balanced with an increase in public knowledge and awareness about the emergency management of dental avulsion during the Covid-19 pandemic, which is presented from an educational animated video.

Keywords: Dental avulsion, periodontal ligament, dental replantation, dentoalveolar trauma

\section{PENDAHULUAN}

Trauma dentoalveolar merupakan cedera yang dapat menyebabkan kehilangan gigi dan menimbulkan masalah fungsional, psikologis dan estetika. Avulsi gigi permanen atau terlepasnya gigi dari soketnya tergolong dalam kondisi kedaruratan dental karena menyebabkan kerusakan parah pada jaringan pendukung, struktur vaskular dan saraf (Poi et al., 2013). Avulsi pada gigi permanen biasanya terjadi karena jatuh, kecelakaan, perkelahian, dan cedera olahraga (Adnan et al., 2018). Penyebab trauma gigi pada anak-anak adalah karena jatuh saat bermain, baik di luar maupun di dalam rumah dan saat berolahraga (Baharin et al., 2019). Avulsi gigi umumnya terjadi pada gigi insisivus sentral rahang atas (Inayah, 2018).

Tingkat keberhasilan gigi avulsi yang ditanam kembali atau replantasi gigi tergantung pada kelangsungan hidup sel-sel ligamen periodontal yang tersisa di permukaan akar, integritas sementum akar dan kontaminasi bakteri yang minimal, waktu penyimpanan, jenis media penyimpanan setelah avulsi dan perubahan permukaan akar (Khinda et al., 2017). Perawatan ideal untuk gigi permanen avulsi adalah penanaman kembali segera ke soket. Pengalaman klinis menunjukkan bahwa replantasi gigi secara langsung jarang dilakukan karena faktor-faktor yang terkait dengan kecelakaan itu sendiri, seperti adanya cedera kepala ataupun bagian tubuh lain yang mengancam jiwa, kerusakan kompleks pada soket gigi, kondisi psikologis pasien atau kurangnya pengetahuan atau kepercayaan dari masyarakat umum dan bahkan para profesional tentang prosedur replantasi gigi ini (Poi et al., 2013).

Berbagai penelitian menunjukkan bahwa replantasi gigi segera yaitu sekitar kurang dari 60 menit akan memberikan tingkat kesembuhan yang baik (Abraham et al., 2021). Permasalahan yang dihadapi adalah kurangnya pengetahuan sebagian besar masyarakat tentang tatalaksana avulsi gigi dan media penyimpanan yang tepat, terutama di masa pandemi Covid-19 (Uzarevic et al., 2020). Oleh karena itu perlu dilakukan kampanye edukasi tentang dengan sasaran masyarakat umum. Penyampaian informasi melalui video animasi lebih efektif daripada media cetak untuk meningkatkan angka keberhasilan perawatan avulsi gigi (Firdaus, 2016; Angelina F, 2019; Amalia et al, 2020). Pengabdian masyarakat ini bertujuan untuk memberikan pengetahuan kepada masyarakat umum terhadap penatalaksanaan avulsi gigi di masa pandemi Covid-19 sehingga setelah dilakukan kegiatan ini dapat meningkatkan pengetahuan dan merubah perilaku masyarakat dalam hal mendukung perawatan avulsi gigi. 


\section{MASALAH}

Kegiatan ini dilakukan di Samarinda dengan berdasar pada kondisi pandemi Covid-19 yang masih berlangsung hingga saat ini. Adanya pembatasan sosial yang dianjurkan oleh pemerintah mengakibatkan kegiatan pengabdian masyarakat didominasi dengan pemanfaatan media online sebagai sarana edukasi kepada masyarakat.

\section{METODE}

Sasaran kegiatan pengabdian masyarakat ini yaitu seluruh masyarakat umum di Indonesia. Metode pelaksanaan pada program kegiatan pengabdian kepada masyarakat ini disusun menjadi beberapa tahap.

\section{a. Tahap Persiapan}

Kegiatan yang dilakukan pada tahap persiapan adalah :

1. Persiapan materi edukasi dan kuesioner dengan google form

2. Pembuatan video animasi edukasi

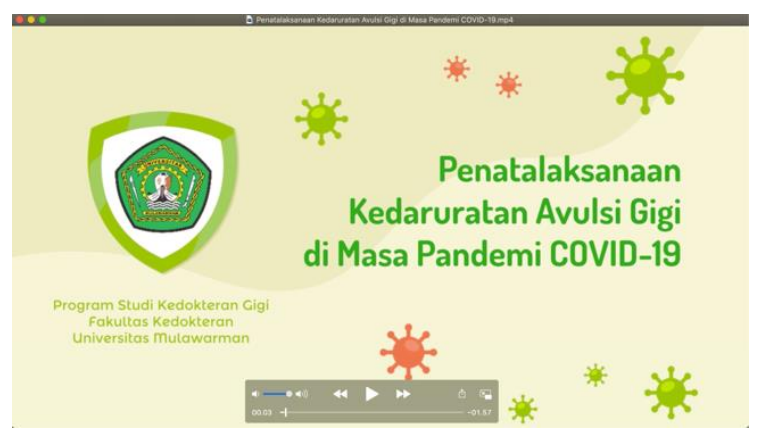

Gambar 1. Video animasi edukasi yang siap diunggah dengan format .mp4

\section{b. Tahap Pelaksanaan Kegiatan}

Kegiatan pengabdian dilakukan pada bulan November 2020 dengan cara mengunggah video animasi edukasi di platform video online "YouTube" dan membuat format tautan video yang disebar ke berbagai platform digital "WhatsApp". Setelah masyarakat dapat mengakses dan menyimak video animasi edukasi tersebut, akan diberikan kuesioner yang dapat diisi yaitu berupa google form untuk mengetahui tanggapan responden terhadap video edukasi yang telah dilihat. 


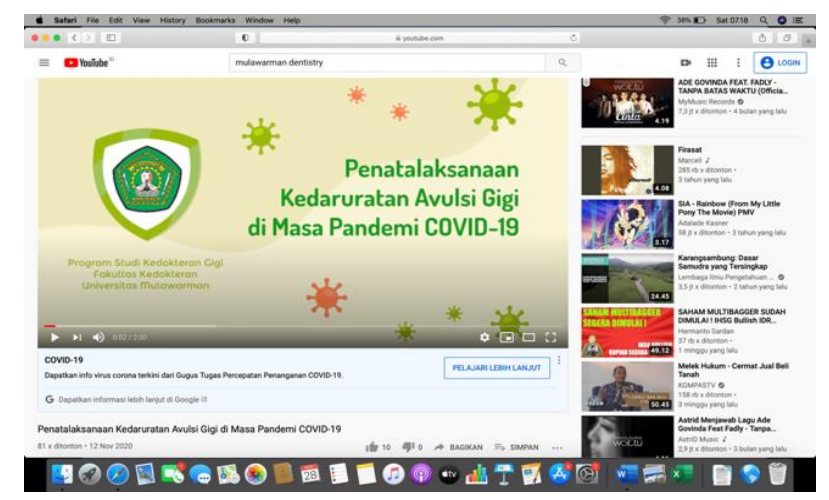

Gambar 2. Video animasi edukasi yang telah diunggah

di platform video online "YouTube"

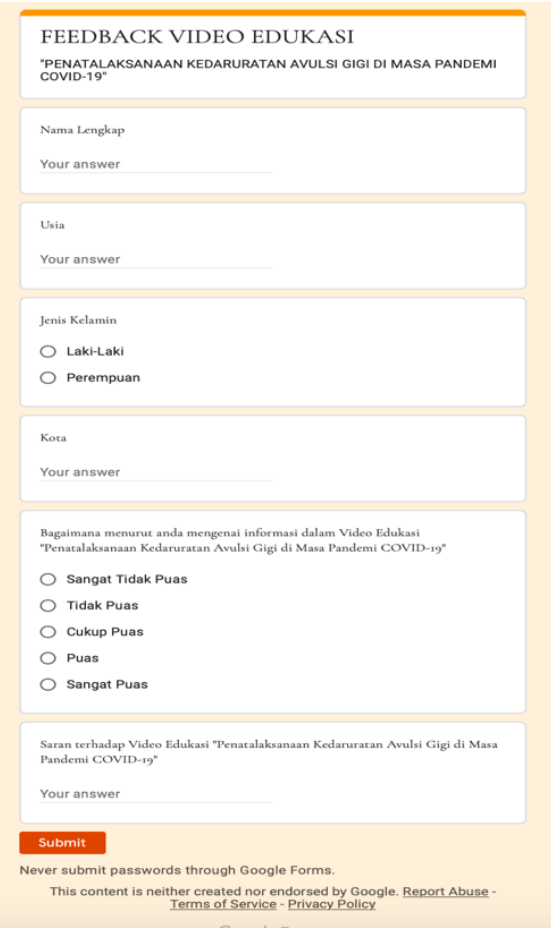

Gambar 3. Google form dengan tautan :

https://docs.google.com/forms/d/e/1FAlpQLSeKAJzISoKrmZan4l3rbndsy_2mC8 watIXVOGyMOZHuqRmG8w/viewform

\section{c. Tahap Evaluasi}

Tahap evaluasi merupakan tahapan yang dilakukan untuk menilai kegiatan secara keseluruhan dan meninjau kembali adanya kekurangan selama kegiatan. Tahap evaluasi ini bertujuan agar kegiatan yang dilakukan dapat berjalan dengan efektif dan sesuai dengan yang diharapkan. Selain itu tahap evaluasi juga difokuskan terhadap analisis dari kuesioner melalui google form yang telah dikumpulkan. Dari hasil pengisian kuesioner oleh masyarakat yaitu 50 orang didapatkan sebanyak $50 \%$ sangat puas ; $46 \%$ puas ; $2 \%$ cukup puas ; $0 \%$ tidak puas ; 
dan $2 \%$ sangat tidak puas terhadap video edukasi yang ditayangkan di platform YouTube tersebut.

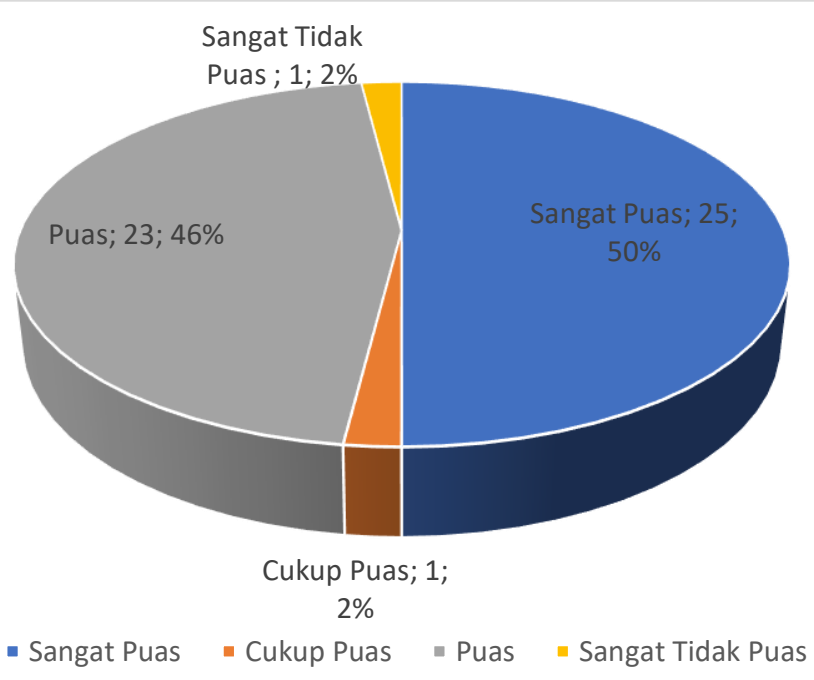

Gambar 4. Diagram tanggapan masyarakat tentang tingkat kepuasan masyarakat terhadap video animasi edukasi melalui pengisian google form

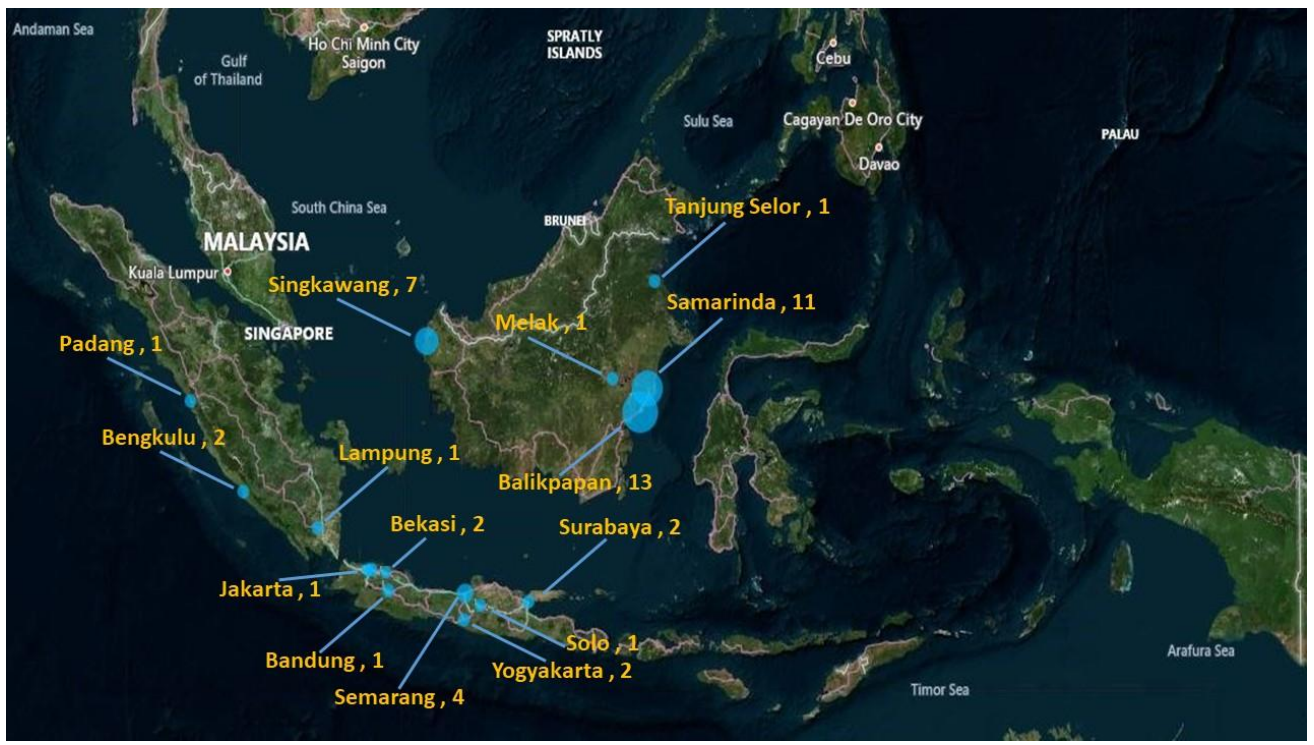

Gambar 5. Peta sebaran data masyarakat yang mengisi kuesioner

\section{HASIL DAN PEMBAHASAN}

Hasil yang telah dicapai dari kegiatan pengabdian kepada masyarakat ini yaitu terciptanya video animasi edukasi yang diunggah di platform Youtube dan dapat dinikmati oleh seluruh masyarakat luas. Adanya penambahan masif jumlah pasien yang terinfeksi Covid-19 di Samarinda membuat terbatasnya kegiatan pengabdian kepada masyarakat secara langsung, sehingga kegiatan ini dinilai paling efektif untuk menjangkau seluruh masyarakat bahkan untuk masyarakat di luar Samarinda. Kendala yang dihadapi pada kegiatan ini yaitu pada persiapan 
kegiatan dan pelaksanaan kegiatan. Pada tahap persiapan kegiatan, dilakukan pengumpulan materi yang terkait dengan tatalaksana avulsi gigi di masa pandemi Covid-19. Namun belum banyak sumber referensi yang memadai sebagai rujukan karena masalah pandemi Covid-19 masih merupakan hal yang baru di tahun 2020.

Pada tahap pelaksanaan kegiatan, dilakukan pemberian tautan video edukasi melalui platform digital "WhatsApp" yang disebar ke kelompok masyarakat luas. Hal ini dikarenakan adanya pandemi Covid-19 sehingga mengakibatkan keterbatasan dalam distribusi video edukasi. Selain itu, kendala yang terjadi adalah pengguna media sosial yang menerima tautan tersebut belum tentu bersedia untuk menyimak video edukasi maupun mengisi tanggapan (feedback) mengenai materi yang diberikan. Kendala yang lain adalah keterbatasan pada masyarakat yang tidak mempunyai smartphone atau akses internet tidak dapat mengakses video edukasi tersebut. Faktor yang mendukung kegiatan ini yaitu tersedianya platform digital "YouTube" dan "WhatsApp" sebagai media sosial yang memungkinkan video edukasi dapat diakses oleh masyarakat di manapun dan kapanpun. Video edukasi yang telah diunggah ke media sosial dapat diakses kapanpun tanpa ada batasan sehingga perlu dilakukan sosialisasi yang dilakukan berkala dengan cara distribusi tautan video edukasi ke berbagai platform digital.

Hal yang perlu dipertimbangkan dalam penyusunan strategi adalah menentukan pesan utama. Pesan utama jika dijelaskan secara sederhana adalah pesan utama yang ingin disampaikan dalam keseluruhan rangkaian kegiatan pengabdian masyarakat. Tujuannya adalah agar pesan yang disampaikan dapat dengan mudah diterima secara menyeluruh dan koheren baik secara logika maupun emosional oleh masyarakat. Pesan utama harus ditentukan di awal pelaksanaan program media sosial institusi untuk menjaga kesinambungan pesan yang hendak disampaikan. Selain itu perlu juga memperhatikan tanggapan dan saran dari masyarakat yang telah mengisi kuesioner. Masyarakat umum modern adalah masyarakat yang kritis terhadap informasi. Di era keterbukaan seperti saat ini, masyarakat lebih mempercayai informasi dari media sosial dan media informasi lainnya. Media sosial dapat menjadi solusi karena dapat menjangkau khalayak secara lebih personal dan komunikatif. Dampak sosial dari kegiatan ini yaitu perubahan sosial. Perubahan sosial yang terjadi yaitu perubahan gaya hidup atau pola kehidupan masyarakat untuk lebih memperhatikan kondisi kesehatan gigi terutama bila terjadi avulsi gigi.

\section{KESIMPULAN}

Kegiatan pengabdian masyarakat ini mampu meningkatkan pengetahuan dan kesadaran masyarakat di Indonesia tentang penatalaksanaan kedaruratan avulsi gigi di masa pandemi Covid-19 yang disajikan dari video animasi edukasi. Saran untuk penyelenggaraan kegiatan yang serupa dengan memperhatikan hal berikut yaitu perlu adanya peningkatan kualitas konten maupun tampilan untuk video edukasi pengabdian masyarakat berikutnya. 


\section{DAFTAR PUSTAKA}

Abraham, Y.; Christy, R.; Gomez-Kunicki, A.; Cheng, T.; Eskarous, S.; Samaan, V.; Khan, A.; Sholapurkar, A. (2021). Management of Dental Avulsion Injuries: A Survey of Dental Support Staff in Cairns, Australia. Dent. J. 9, 4.

Adnan, S., Lone, M.M., Khan, F.R., Hussain, S.M., Nagi, S.E. (2018). Which is the most recommended medium for the storage and transport of avulsed teeth? A systematic review. Dent Traumatol. 34:59-70.

Amalia N, Wulandari YA. (2020). Efektivitas Penggunaan Media Video Pencegahan Secondhand Vape Smoker Terhadap Risiko Secondhand Vape Smoker di UMKT. Jurnal Dunia Kesmas Vol. 9(4):491-499

Angelina F., Nuryani D.D, Elviyanti D. (2019). Efektifitas Pemanfaatan Media Gambar Bergerak dan Video Animasi terhadap Peningkatan Pengetahuan dan Sikap Ibu tentang Gizi Seimbang pada Balita. Jurnal Kesehatan (10) 2 : 181-186.

Baharin F, Osman NF, Adnan MM. (2019). Knowledege and attitude towards dental trauma management among primary school teachers. Padjadjaran Journal of Dentistry. 31(3): 161-166.

Firdaus. (2016). Efektivitas Penggunaan Media Audio-Visual dalam Pembelajaran Sains. SPEKTRA : Jurnal Kajian Pendidikan Sains 2(01), 46-54.

Inayah, Y., Herdiyati, Y. (2018). Penanganan Avulsi Dua Gigi Permanen Pada Anak Usia 12 Tahun. Indonesian Journal of Paediatric 1(1):86-91

Khinda VIS, Kaur G, Brar GS, Kallar S, Khurana H. (2017). Clinical and Practical Implications of Storage Media used for Tooth Avulsion. Int J Clin Pediatr Dent.10(2):158-165.

Poi W.R, Sonoda C.K., Martins C.M., Melo M.E., Pellizzer E.P., de Mendonca M.R., Panzarini S.R. (2013). Storage Media For Avulsed Teeth : A Literature Review. Brazilian Dental Journal 24(5): 437-445.

Uzarevic Z, Ivanisevic Z, Karl M, Tukara M, Karl D, Matijevic M. (2020). Knowledge on Pre-Hospital Emergency Management of Tooth Avulsion among Croatian Students of the Faculty of Education. Int. J. Environ. Res. Public Health 17(7159):1-9 doi:10.3390/ijerph17197159. 